\title{
The Ability of Traditional and Modern Performance Indicators in Interpreting the Phenomenon of Earnings Management: Evidence Manufacturing Firms in Amman Stock Exchange
}

\author{
Dr Mohammad Abdallah Almomani \\ Accounting Department, Jadara University \\ E-mail: momani@Jadara.edu.jo
}

Received: Jan. 26, 2016 Accepted: March 17, $2016 \quad$ Published: June 1, 2016

doi:10.5296/ajfa.v8i1.8943 URL: http://dx.doi.org/10.5296/ajfa.v8i1.8943

\begin{abstract}
The study objects for investigating the ability of traditional and modern performance indicators in interpreting earnings management phenomena of listed manufacturing firms in the Amman Stock Exchange (ASE), using adjusted Jones method for measuring earnings management. The study takes into considerations three traditional indicators, including; Return on Assets (ROA), Return on Sales (ROS), and Operating Cash Flow, while the Market Value Added (MVA), Tobin's-Q, and Economic Value Added (EVA) are used as modern indicators for financial performance. A sample consisted of 29 firms had been selected, and data covering the period 2006-2013 had been collected from these firms, where 232 observations were used in the analysis. The study found that the earnings management of listed manufacturing firms at (ASE) still practice the phenomenon of earnings management, at low level based on the measures followed by the study, and that there is a significant linear relationship between performance indicators (traditional and modern) and earnings management. The results indicate that there is a significant as well inverse relationship between (ROA) and earnings management. Also, the study found that modern performance indicators are able to interpret earnings management, where the results indicate that there is a significant as well as inverse relationship between (EVA), and (Tobin's-q) and earnings management. One important finding showed that (EVE) is effective and followed by (Tobin's-q) indicator in interpreting the earnings management phenomena. However, the study did not show a significant relationship between CFO, LEV Ratio, ROS, and MVA with earnings management. Based on these results, the study made many recommendations to the
\end{abstract}




\section{Macrothink

interested parties and the most important one is that companies must disclose the economic value added in the financial statements to enable investors and related parties to be aware of the amount of value-added that lead to increase the wealth of shareholders, and to help managers to consider all costs of capital. In addition, these indicators can be used with other indicators such as (ROA, ROE) to evaluate firm's performance.

Keywords: Earnings Management, Modern Performance Indicators, Traditional Performance Indicators, Industrial Companies, Amman Stock Exchange (ASE) 


\section{Introduction}

Financial reports are the main source of financial performance that investors, creditors, and other parties depend on to receive necessary information for decision making. To be beneficial, this information should be reliable and relevant. Literature accounting has taken care of the issue of intentional interventions by managements in the content of the announced accounting information. This intervention focuses on the measurement and disclosure of accounting operations for profit and result in either inflating the profits or reduce or the stability of the levels to serve their interests, so associated with the benefit that you get by management through the practice of earnings management. Often managements intervene in the earnings reporting process in order to influence the reported income figures for their own benefits, in this case, managers have engaged in earnings management. Earnings management involves the alteration of financial reports to mislead stakeholders about firms underlying performance. Generally accepted accounting principles (GAAP) offer some flexibility in preparing the financial statements and give the management some freedom to select among accounting policies and alternatives approaches of measurement. Earning management occurs when managers use judgment in financial reporting and in structuring transactions to alter financial reports (Healy and Whalen, 1999). Earnings management has a negative effect on earnings quality, and may weaken the credibility of financial reporting process. Lo(2008), shows highly managed earnings can yield low quality earning.

Earnings management is one among the important issues nowadays in the minds of investors and accounting standard setters, especially next to financial scandals and crises, occurred by the starting of the current century, where users' trust in financial reports declined, if not missed. The identifying signals of earning quality would be useful to investors and others. Accounting, market, and economic performance indicators are important in the measurement of firm's performance, which is used to make necessary comparisons and analyses. There are some studies where it used accounting performance indicators such as Return on Assets (ROA), Return on Equity (ROE), and Return on Sales (ROS). Boardman and Vining, (1989), showed that the accounting performance indicators, still have a wide spread use as a measure of performance, whereas Haddad and Haddad, (2003) showed that investors are focusing on reported accounting profits in the financial statements of firms when making their decision investment and when building their expectations and evaluate their investments, as they have a significant impact on the reversing information on future profits and therefore the impact on the price of market share of the company.

The traditional accounting indicators are used to assess the status of the company including, ROA, ROE, EPS, and Operating Cash flows (OCF), have faced several criticisms of their reliance on estimate. These indicators are also influenced by the followed accounting method, since the rate of returns on accounting yield has always been criticized for its inability to measure the economic profit (Fisher and McGowan, 1983),. In addition, the financial reports has been criticized because of low quality and the lack of correlation where the environment is rich with information, (Mashayekhi and Bahavarnia, 2007), and there was almost a general consensus that traditional methods must be reviewed to overcome the defects. 
In the early eighties, Stern Stewart has announced a new measure of performance called the term economic value added (EVA). The entrance of economic value added as a tool to measure the internal and external performance of the company takes into consideration the cost of capital (O'Byrne, 1996). It was found that the economic value-added measure is one of the best performance metrics that have emerged in recent times. Grant, (1996) asserted that the economic value-added measure is a proper way to measure profitability. Stern and Stewart (1995), defined economic value added as "the difference between the net operating profit after tax and average cost of owned capital. When the EVA $>0$, it can be considered as good indicator for firms success, because there is an increase in the wealth of owners, Whereas when the $E V A=0$, there is a probability that the firm produces as much as the funds invested, but when if $E V A<1$, the means that there is a decrease in the wealth of owners.

Currently, increased attention around the world has risen to create economic value. The driving force behind this attention is the increase in the intensity of competition and the interest of investors out more effectively. So there is a need to provide more accurate tools instead of depending various standard methods such as Value Based Management (VBM), which provides awareness of a high degree of value of shares and Economic Value Added (EVA), which was developed by the American company entitled Stern Stewart in 1989, all of these methods work to provide more accurate standardized methods compared with the traditional methods of accounting, especially where accounting rate of return is criticized of its inability to measure the economic profit (Fisher and McGowan, 1983).

Traditional performance measurement systems were designed to measure performance and accountability to confirm that people meet their budget and followed orders. This encourages managements to practice earnings management by using many alternative methods of accounting measurement. These practices found that all of ROA, ROE, EPS, and revenue growth can be adjusted by altering accounting methods or capital structure. O`Byrne (1996), found that returns only explain $24 \%$ of the change in the market value of a firm. However, relying on the amount of net profit only, without taking into account the factors that lead to reduction in the level of quality, such as the practice of earnings management, and the high proportion of accruals, affects the safety of the decisions taken by stakeholders, so the focus is on the profit level while the quality of the profit is neglected. (Chan et al, 2006, pp, 1041-1082).No common agreement yet is available for the definition of the term earnings quality. Sloan (1996), indicates that the quality of earnings sustainability of cash flows means more continuity receivables, while Schipper and Vincent, (2003) showed that earnings quality is the reduction in the differences between the accounting reported income and economic income. Ghosh and Moom (2010), demonstrated that earnings quality is the ability of earnings to predict future cash flows. Moreover, Bellovaryet al, (2005), stated that earnings quality is achieved when the reported earnings reflect the actual performance, and can be used in predicting future earnings, so earnings quality is represented by the continuity of earnings. While Teets (2002), found that some people look to the quality of earnings during the term reflected in the economic performance of companies, and others see the quality of profits by the extent to which they contain information from accounting profits reflecting the economic performance of companies. Fariha and Moreira (2007), have defined the quality of 
earnings as profits devoid of the use of certain accounting options to get to figure profit target, especially accounting options that lead to report earnings for future periods in the current period, or vice versa. In addition, Bagaeva (2010), defined the quality of earnings on the basis of the timing of recognition of economic losses in the income statement.

Based on the above mentioned definitions and descriptions for the term of earnings quality, it is apparent that earnings quality stems its importance from the accounting income, which can be considered the most important resource of accounting information for investors, creditors, and other users of accounting information through the different accounting reports. Earnings quality is important for users of accounting reports, since it enables them to take good decisions, evaluate manager's performance, evaluate the financial position of the firm, and estimate the future expected earnings.

Prior researches mentioned different measures for the determination of earnings quality level. Several recommendations for the interpretations of earnings quality are available; among these is the use of earnings continuity as indicator for quality. Sloan (1996), showed that earnings quality means cash flows continuity at a higher rate of accruals continuity. Richardson, et al, (2005), developed a model for the measurement of future profits continuity. Other prior researches used accruals method for measuring earnings quality using the absolute value of discretionary accruals. To compute discretionary accruals Jones method (1991), which adjusted by Dechow et, al, (1995) can be used. This method is the most common used method for earnings management measurement, and can also be used for measuring earnings quality. That is a higher absolute value of discretionary accruals suggests lower earning quality.

The market performance indicators that measure the investment attractiveness of firm's shares to the dealers in the financial market, and measure the extent of the company's management's ability to maximize the wealth of owners, Panahaian and Hosseini (2013), found a lack in the statistically of the significant relationship between market performance of proportion (Tobin's-q) and the equality of reporting, and there is a significant and positive relationship between the market added value and quality of the financial reports, as measured by the quality of financial reporting standards quality profits. Panigrahi, et al. (2014), showed that earning per share as a traditional measure still enables the measurement of shareholders' creation. In addition, the study shows that EVA was not used by investors for their investment decisions. Nakhaei and hamid (2013), indicated that there are more association between accounting variables and share market value, than economic value added, and the significant relationship between EVA and market value. Peixoto (2002), shows that economic value added does not have more information content than traditional performance measures in explaining equity market value.

Under the changing economic developments, the financial performance of firm and its measures became one among today's hot issues. Where traditional accounting measures became less useful, new modern measures appeared. Modern Economic measures are more useful than traditional measures, especially where these measures can identify the quality of earnings. 
Therefore, the study investigates the ability of traditional and modern performance indicators to interpret the phenomenon of earnings management. Based on this discussion, the problem of the study can be well presented through the following questions:

1-Are the traditional accounting performance indicators of ROA, ROE, CFO able to interpret the phenomenon of earnings management of the listed manufacturing firms in the Amman Stock Exchange (ASE)?

2- Are the modern performance indicators (market and economic) able to interpret the phenomenon of earnings management of the listed manufacturing firms of ASE? Two branch questions are stemmed from this question, as follows:

A- Are the market performance indicators consisting of MVA, and Tobin's-q, able to interpret the phenomenon of earnings management of ASE?

B- IS EVA as an economic performance indicator able to interpret the phenomenon of earnings management of listed manufacturing firms in ASE?

The study objects for investigating whether the traditional and modern performance indicators are able to interpret the phenomenon of earnings management. This objective can be better expressed through the following sub-objectives:

1- To determine the ability of accounting performance indicators (ROA, ROE, and CFO) in interpreting the phenomenon of earnings management that the listed manufacturing firms in ASE may exercise.

2- To determine the ability of market performance indicators (MVA, and Tobin's-q) in interpreting the practice of earnings management phenomenon by the listed manufacturing firms in ASE.

3- To determine the ability of economic performance indicators (EVA) in interpreting the phenomenon of earnings management that may be exercised by the listed manufacturing firms in ASE.

This study is important because it investigates a topic that recently became on focus of accounting literature, next to firm's scandals and firm's collapses. Experts and professional people interpreted the firm collapses by the manipulation practices in those firms there managements. The managements of those firms exploited the level of flexibility that available in accounting methods, where more than one accounting method can be used to account for each item of the financial statements. As a result, the announced information of collapsing firms did not reflect the actual economic events occurred during accounting periods, so the financial positions and results of operations of those firms were overstated. The importance of the study also increases because it is considered an attempt to interpret the phenomenon of earnings management by using modern metrics of performance indicators of the economic and market. The findings of the study will be beneficial and important for different parties including, shareholders, managements, creditors, and other interested users, because the quality of the reported represents an important aspect in the assessment of 
financial position, and in estimating future earnings, in addition to its importance in the decision making process that users are required to take.

This research is organized as follows: section 2, covers the related prior researches, while the related literature is provided in section 3. Section 4 presents the hypotheses of the study whereas section 5 shows the methodology used in the study. Section 6 shows the analysis of the data and hypotheses testing, and section 7 explores the findings and the conclusions.

\section{Prior Researches}

Several prior researches investigated some aspects of the earnings management phenomenon. Some of these researches were based on a questionnaire, while others are based on secondary available data. Despite that, some aspects had not been given the deserved importance by researchers, and still they need more and more investigations.

Panigrahi, et, al.2014), compared between the traditional and economic performance measures for creating shareholders value. The study had been based on a sample consisted of (28) construction public listed firms in main board of Bursa Malaysia over the period 2003-2012.The study revealed the existence of a positive and significant relationship between economic value added (EVA) and shareholder's wealth maximization. The study also shows that earnings per share as a traditional measure still enables the measurement of value creation for shareholders. In addition, the study shows that the EVA was not used by investors for their investment decisions.

Ongeri (2014) carried out an empirical to investigate the relationship between Economic Value and Accounting Value among commercial banks in Kenya as a basis of company value. This study is based on a survey that encompasses a target population consisting of 43 commercial banks in Kenya, where a sample consisting of 30 commercial banks had been used among that population. Secondary data of published financial reports was used to achieve the objectives of the study over the period 2008-2012, encompassing 150 observations. The econometric results reveal that both ROI and Earnings per Share (EPS), have a significant positive relationship with Economic Value. On the other hand, the findings show an inverse relationship between ROE and Economic Value

Panahaianand Hosseini (2013), investigated the effects of performance criteria including accounting, market, and economy, on the quality of financial reporting. The statistical population research consisted of the companies listed on Tehran Stock Exchange over the period 2006-2011. The results of the tests that conducted on 99 firms indicate that there is a significant positive relation between ROE, and EPS from one hand, and the quality of financial reporting on the other hand. In addition, the study shows no relationship between Tobin's-q and the quality of financial reporting. Finally, the results indicate the existence of a significant positive relation between market-value added and the quality of financial reporting.

Nakhaei and hamid (2013), examined the relative explanatory power of the economic value added (EVA) model with respect to share market value (MV) compared to recognized accounting variables (net profit and operational profit)in Tehran Stock Exchange. The study 
was based on a sample consisting of 87 non-financial firms over the period 2004-2008. The results indicated there the availability of more association between accounting variables and share market value than economic value added. Moreover, the study found a significant relationship between EVA and market value.

Hamdan (2012), examined the factors affecting the level of earnings quality in different types of firms. Accounting conservatism, company size, debt contracts, return on investment, corporate governance, auditing quality and audit committees, all of these factors had been investigated in their effect on earnings quality. The study sample consisted of 50 listed in ASE, over the period 2009-2004. The study shows the existence of a high level of earnings quality in Jordanian industrial corporations. It also found evidence that company size, debt contracts and auditing quality have effect on earnings quality.

Naimi(2012), investigated the relationship between the equation (Tobin's-q) each of stock price, market value to book value per share (MV/BV) and price per share, based on a sample of 10 listed firms in the Iraq Stock Exchange. The study found that the modern performance measure (Tobin's-q) expresses the real situation of firms more than traditional scale (MV / $\mathrm{BV}$ ), and the reliance on a scale (Tobin's-q) provides an appropriate opportunity for investors to predict future performance and profitability.

Nassirzadeh.et, al. (2012), examined the factors affecting earnings management of listed companies in Tehran Stock Exchange. So, the effects of the debt-equity ratio, firm size, managers' bonus and effective tax rate on earnings management are examined. The sample of the study consisted of 114 listed firms in Tehran Stock Exchange over the period 2006-2010. The results indicate that there is a significant as well inverse relationship between debt to equality ratio and earnings management. Moreover, it shows a significant positive relationship between firm size and earnings management. However, the study did not find a significant relationship between changes in managers' bonuses and the effective tax rate with earnings management.

Radwan (2011), investigated the nature of the relationship between economic indicators (EVA and MVA), and indicators of traditional accounting performance (Return on Investment and ROE) in one hand, and stock returns in the other hand.The study was conducted based on a sample of 34 registered firms in the Saudi Stock Market over the period 2009-2005. The study showed that traditional accounting performance indicators were more capable of economic performance indicators in the interpretation of changes to stock returns. The study also revealed that the accounting and economic performance indicators together were able to interpret $26 \%$ of the changes in stock returns, which highlights the importance of measurement and disclosure of economic performance indicators, as well as the accounting of performance indicators, in order to assist management in maximizing the wealth of owners through making investment decisions that achieve returns to investors.

ALDabbas (2007), carried out a study to investigate the relationship between economic evaluation metrics (EVA, the value of the modified economic value added, MVA, and residual income) and accounting evaluation metrics (ROA, ROE, net profit, and operating cash flows) in one hand, and performance of firms, in the other hand. The study found that 
the economic assessment indicators have a significant effect on firm's performance, and there are differences between the economic performance indicators and accounting performance indicators in assessing the performance of firms.

Irala (2005), concluded that EVA is considered a better measure of performance than the traditional measures such as ROE, EPS, ROI, and the profit measures. EVA used as a performance measure stimulates managers to employ a firm's assets more productively and it assists in reducing differences in the interests of the managers and shareholders.

Peixoto (2002), investigated the relationship between operating profit, net profit, and EVA with firm's market value. The study had been prepared based on a sample consisting of 39 listed firms in Lisbon Securities Stock Exchange of Portugal, along the period 1995-1998. The main conclusion of the study is that a correlation exists among EVA, operating profit, and net profit, with market value. The study also shows that EVA does not have more information content than traditional performance measures in explaining equity market value.

Dechowand Dichev (2002), suggested a new measure of one aspect of the quality of working capital, accruals, and earnings. One role of accruals is to shift or adjust the recognition of cash flows over time, so that the adjusted amount of earnings measures in a better form the financial performance of firms. The sample of the study consisted 1,725 firms, had been obtained from the Compust at Annual Industrial and Research files, along the period 1987-1999. The study derives an empirical measure of accrual quality as the residuals from firm-specific regressions of changes in working capital on past, present, and future operating cash flows. The study finds that the measure of accrual quality is positively related to earnings persistence, and the most important conclusion is that everything equal large accruals signify low quality of earnings, and less persistent earning.

ALKhalayleh (2001), investigated the relationship between the accounting performance indicators of market performance, and market indicators such as EPS in the long-range. The study was conducted based on a sample consisting 40 manufacturing listed firms in ASE 0ver the period 1996-1984. The results showed the existence of a statistically significant positive relationship between the return on the stock market and all of ROA, ROE, and that the relationship between EPS and accounting performance indicators (ROE, ROA) be strong whenever it increased probationary period

Sloan (1996) identifies the source of information in accruals about earnings quality. The results show that information in accruals about earnings quality originates from both growth in the scale of operations and deterioration in the efficiency of asset usage. The main conclusion of the study is that a total accruals, defined as the difference between earnings and free cash flows, provide an intuitive, robust and parsimonious measure of earnings quality. Also results indicate that the information in accruals about earnings quality is not attributable to a single factor, such as 'discretionary' accruals or firm growth.

Based on the above related research, it is noted that most of prior researches had addressed a relationship between EVA, market value per share, and their ability to explain the change in the market value of the shares. Some prior researches focused on the comparison between the 
nature of the relationship between traditional measurement methods and their ability such as: ROA, ROE and CFO, where all the studies focused on the effect of the EVA on the market value of shares, or studied the relationship between them. This study is different where it investigating the extent of performance indicators of economic, market, and accounting in interpreting the phenomenon of earnings management to show the benefits of these indicators for users of financial statements to enable them to take good decisions.

\section{Study Hypotheses}

Based on the survey made of the related literature and prior researches of traditional,modern performance indicators and earnings quality, two key hypotheses had been developed in there null form. These two hypotheses are as follows.

Ho: : Traditional Performance indicators including Return on Assets, Return on Sales, and Cash Flows from Operations, are unable to interpret the phenomenon of earnings management that the manufacturing listed firms in Amman Stock Exchange may exercise

Ho2: Modern performance indicators including market and economic indicators are unable to interpret the phenomenon of earnings management that the manufacturing listed firms in Amman Stock Exchange may exercise.

To simplify the test of the second hypothesis, two sub-hypotheses had been derived as listed below, in their null form.

Ho $21_{2}$ : Indicators of market performance included the Added Market Value and the Firm's Opportunity of Growth (Tobin's-Q), are unable to interpret the phenomenon of earnings management that may be exercised by the listed manufacturing firms in Amman Stock Exchange.

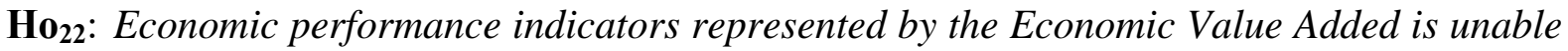
to interpret the phenomenon of earnings management that may be exercised by the listed manufacturing firms in Amman Stock Exchange.

\section{Methodology}

The population of the study includes all manufacturing listed firms in ASE. The number of listed manufacturing firms in ASE is 68 firms, by the end of 2013. A portion of needed data for the measurement of the study variables requires the availability of data one year before the period of the study, which is extended over the period 2006-2013. Number of observations that were subject to analysis is (232), attributed to 29 listed manufacturing firms in ASE for 8 year period, so this composes (42.6) percent from the total population of the study. Actually, two terms should be available in a firm in order to be included in the sample. First, all needed data regarding the firm should be available; whereas the second is that the firm was not stopped or merged with other entity during the period of the study. Based on the literature, the earnings quality is one of the most important factors of assessing and determining the value of an organization. 


\section{Macrothink}

The study adopted the Jones method (1991), which adjusted by Dechow and et.al, (1995) for measuring earnings management, which is considered as the most famous model to detect earning management nowadays. The model is based on using the discretionary accruals as an indictor of earnings management. That is a higher absolute value of discretionary accruals suggests lower earning quality. The absolute value of discretionary accruals is viewed as an inverse measure of earnings quality. To compute the absolute value of discretionary accruals, the following equation can be used.

Total accruals (TA) are measured as follows:

$$
T A_{i, t}=N I_{i, t}+C F O_{i, t}
$$

Where:

$\mathrm{NI}_{\mathrm{i}, \mathrm{t}}$ : Net income of firm $\mathrm{j}$ for year $\mathrm{t}$.

$\mathrm{CFFO}_{\mathrm{i}, \mathrm{t}}$ : Cash flows from operations of firm $\mathrm{j}$ for year $\mathrm{t}$.

In order to estimate discretionary accruals for firm $\mathrm{i}$ in year $\mathrm{t}$, we first estimate parameters of the cross-sectional modified Jones (1991) model using all other firms in the same industry (same first two-digit SIC as firm i). The model is as follows:

$$
\frac{T A_{j, t}}{A_{j, t-1}}=\alpha_{j, t}\left(\frac{1}{A_{j, t-1}}\right)+\beta 1_{j, t}\left[\left(\Delta R E V_{j, t}-\Delta R E C_{j, t}\right) / A_{j, t-1}\right]+\beta 2_{j, t}\left[\frac{P P E_{j, t}}{A_{j, t-1}}\right]+\varepsilon_{j, t}
$$

Where :

$\mathrm{TA}_{\mathrm{j}, \mathrm{t}}=$ Total accruals of industry $\mathrm{j}$ for year $\mathrm{t}$.

$\Delta \mathrm{REV}_{\mathrm{j}, \mathrm{t}}=$ Change in revenue of industry $\mathrm{J}$ between year $\mathrm{t}$ and year $\mathrm{t}-1$.

$\triangle \mathrm{RECE}_{\mathrm{j}, \mathrm{t}}$ : Change in Receivables of industry $\mathrm{j}$ between year $\mathrm{t}$ and year $\mathrm{t}-1$.

$\mathrm{PPE}_{\mathrm{j}, \mathrm{t}}$ : Gross property, plant, and equipment of industry $\mathrm{j}$ industry $\mathrm{j}$ for year $\mathrm{t}$.

$A_{j, t-1}:$ Total assets of industry $\mathrm{j}$ by the end of year $\mathrm{t}-1$.

The industry-specific estimates of parameters from equation (2) imply an expected association between non-discretionary accruals and accounting variables for firms in industry $\mathrm{j}$. Thus, the non-discretionary accruals for firm $i$ in year $t$ can be computed as follows:

$$
\mathrm{NDA}_{i, \mathrm{t}}=\alpha_{j, t}\left(\frac{1}{A_{j, t-1}}\right)+\beta 1_{j, t}\left[\left(\Delta R E V_{j, t}-\Delta R E C_{j, t}\right) / A_{j, t-1}\right]+\beta 2_{j, t}\left[\frac{P P E_{j, t}}{A_{j, t-1}}\right]+\varepsilon_{j, t}
$$

The absolute value of discretionary accruals for firm $\mathrm{i}$ in year $\mathrm{t}$ is computed as follows:

$$
\left|\mathrm{DA}_{\mathrm{i}, \mathrm{t}}\right|=\left|\mathrm{TA}_{i, t}-N D A_{i, t}\right|
$$

Where:

$\mathrm{DA}_{\mathrm{i}, \mathrm{t}}$ : discretionary accruals in year $\mathrm{t}$, that used to measure earnings management.

And it can be placed (the main form), as mathematical as follows: 
$\mathrm{EM}_{\mathrm{i}, \mathrm{t}}=\beta_{0}+\beta_{1} \mathrm{ROA}_{\mathrm{i}, \mathrm{t}}+\beta_{2} \operatorname{ROS}_{\mathrm{i}, \mathrm{t}}+\beta_{3} \mathrm{CFO}_{\mathrm{i}, \mathrm{t}}+\beta_{4} \mathrm{MVA}_{\mathrm{i}, \mathrm{t}}+\beta_{5}$ Tobin's-q $_{\mathrm{i}, \mathrm{t}}+\beta_{6} \mathrm{EVA}_{\mathrm{i}, \mathrm{t}}+\beta_{7}$ Firm's Size $_{\mathrm{i}, \mathrm{t}}+\beta_{8}$ Leverage $_{\mathrm{i}, \mathrm{t}}+\varepsilon_{\mathrm{i}, \mathrm{t}}$

Table 1. Methods and Symbols Used in Variables Measurement

\begin{tabular}{|c|c|c|c|c|}
\hline No. & Criterion & $\begin{array}{l}\text { Type of } \\
\text { variable }\end{array}$ & Variables \& Symbol & Method of calculation \\
\hline 1 & Accounting & independent & Return on assets (ROA) & $\mathrm{ROA}=\frac{\text { Net Profit }}{\text { Average Asset }}$ \\
\hline 2 & Accounting & independent & Return on sales(ROS) & ROS $=\frac{\text { Net Profit }}{\text { SALES }}$ \\
\hline 3 & Accounting & independent & Cash Flow Operations(CFO) & $\begin{array}{l}\text { CFOis divided by total assets for } \\
\text { conversion purposes }\end{array}$ \\
\hline 4 & Market & independent & Market Value Added(MVA) & MVA $=\frac{\text { share Market Value }}{\text { share BookValue }}$ \\
\hline 5 & Market & independent & Tobin's-Q & $\begin{array}{l}\text { Tobin's- } \mathrm{q}= \\
\frac{\text { Corporate Market Value }}{\text { Corporate Book Value }}\end{array}$ \\
\hline 6 & Economic & independent & $\begin{array}{l}\text { Economic Value Added } \\
(\mathrm{EVA})\end{array}$ & $\begin{array}{l}\text { EVA }^{*}=\text { NOPAT }-(\text { WACC } \\
\times \mathrm{IC}) \\
\text { Where: NOPAT is operation } \\
\text { profit after tax, WACC is } \\
\text { weighted average cost of capital, } \\
\text { and } \mathbf{I C} \text { is invested capital. }\end{array}$ \\
\hline 7 & Accounting & Control & Firm Size(FS) & Log.of Total Asset \\
\hline 8 & Accounting & Control & Leverage(Lev.) & Lev $=\frac{\text { Total Debit }}{\text { Total Asset }}$ \\
\hline 9 & Accounting & Dependent & Earnings management(EM) & $\begin{array}{l}\text { Using modified jones model } \\
\text { proposed } \\
\text { byDechowetal.,(1995). }\end{array}$ \\
\hline
\end{tabular}

\section{Results and Analysis}

To examine whether the data is appropriate for analysis and measurement, and whether it achieves the objectives of the study, several tests had been made such as, normal distribution test, multicollinearity test, and correlation. Table (2) shows these tests. 


\section{Macrothink}

Table 2. Test of Data Validity and Study Model

\begin{tabular}{|c|c|c|c|}
\hline \multirow[t]{2}{*}{ Variables } & \multicolumn{2}{|c|}{ Multicollinearity } & \multirow{2}{*}{$\begin{array}{c}\text { Autocorrelation } \\
\text { Durbin Watson }\end{array}$} \\
\hline & Tolerance & VIF & \\
\hline ROA & .594 & 1.684 & \\
\hline ROS & .701 & 1.427 & \\
\hline $\mathrm{CFO}$ & .882 & 1.134 & \\
\hline MVA & .559 & 1.789 & \\
\hline Tobin's-Q & .456 & 2.194 & 1.589 \\
\hline EVA & .645 & 1.551 & \\
\hline Log FS & .495 & 2.020 & \\
\hline LEV. & .842 & 1.188 & \\
\hline EM & .594 & 1.684 & \\
\hline
\end{tabular}

With regard to normal distribution, the study was conducted to include all available data to each firm included in the study sample. In addition, since the sample size composes about 43 percent from the total population of the study, then the model can be considered useful and valid. Tolerance coefficient is computed for each variable, to test the overlapping among variables. Thereafter, the Variance Inflation Factor (VIF) had been used. Since VIF coefficient for each variable is not more than 5 , it is concluded that no overlapping is available among variables, so this means that the model is highly appropriate for interpreting the effect of independent variables on the dependent one. Regarding autocorrelation, Durbin Watson test (D-W) had been used, and its value is 1.65 , so this is a good indicator that autocorrelation problem is not existed among variables. In occasion, the optimal value of $(\mathrm{D}-\mathrm{W})$ test is between 1.5 and 2.5(Gujarati, 2003, P, 496).

\subsection{Descriptive statistics}

Table (3) shows the descriptive statistics for all variables. Based on information appears in the table, it is notable that the mean of the traditional indicators of financial performance (ROA, ROS, CFO) are low, which means that the financial performance was low. When the financial performance is low, this creates an incentive for firms to practice the phenomenon of earnings management, so managements have alternative methods to manipulate these indicators. Regarding the modern indicators of financial performance, they can't be subject to earnings management methods or manipulation. Regarding the mean of MVA and Tobin's-Q, it seems acceptable, and not low, because it is greater than the BV. Considering EM, the means are, in general, minus, which means that firms have good earnings quality. As a result, the management's intervention in earnings measurement is somewhat limited. 
Table 3. Descriptive Statistics of Variables for all companies: 2006-2013

\begin{tabular}{|c|c|c|c|c|c|}
\hline Variable & Minimum & Maximum & Mean & Median. & Standard deviation \\
\hline ROA & -96.49 & 43.94 & 3.2296 & 3.93 & 12.04779 \\
\hline ROS & -358.80 & 160.12 & -1.6547 & 3.77 & 46.55993 \\
\hline CFO & -7.38 & 8.49 & 2.7308 & 5.91 & 5.56495 \\
\hline MVA & -8.34 & 9.46 & .5924 & 5.17 & 6.79991 \\
\hline Tobin's-Q & .01 & 5.10 & .7472 & .59 & .70584 \\
\hline EVA & -4799059 & 79813337 & 2094829 & 57670 & 8542695 \\
\hline FS & 2347989 & 1223269000 & 86110776 & 18814117 & 208897583 \\
\hline LEV. & 1.48 & 79.07 & 32.1721 & 30.02 & 17.01 \\
\hline EM & -110629346 & 87305017 & -1561707 & -169899 & 16074902 \\
& & & & & \\
\hline
\end{tabular}

\subsection{Hypotheses Testing}

The hypotheses of the study object for examining the ability of traditional and modern performance indicators to interpret earnings management phenomenaof the listed manufacturing firms in ASE along the period 2006-2013. At the beginning, I examined the study sample whether the firms of the sample exercise the phenomena of earnings management. Therefore, the mean of the absolute value of the discretionary accruals had been computed, where the rule states that when the value of the discretionary accruals is in excess of the mean, there is a probability that the firm practices the phenomenon of earnings management. In opposite, when that value is less than the mean, there is no probability that the firm does not exercise what is called earnings management. (AL-sartawi, et,. al, 2013). When this rule is applied on the sample of the study, I find that the percentage of companies that do not practice earnings management is $66.2 \%$.

\section{Testing the First Hypothesis}

The first hypothesis had been developed to test whether the traditional performance indicators (ROA, ROE, and CFO) are able to interpret whether the phenomenon of earnings management is exercised by the listed manufacturing firms in ASE. The hypothesis is presented again as follows.

$\mathrm{Ho}_{1}$ : Traditional Performance indicators including Return on Assets, Return on Sales, and Cash Flows from Operations, are unable to interpret the phenomenon of earnings management that the manufacturing listed firms in Amman Stock Exchange may exercise.

The multiple linear regression method had been used in testing the hypothesis. Table (4) shows the results of the study model 
Table 4. Statistical Results of the Traditional indicators

\begin{tabular}{|c|c|c|c|c|}
\hline \multicolumn{5}{|c|}{$\mathrm{EM}_{\mathrm{i}, \mathrm{t}}=\beta_{0}+\beta_{1} \mathrm{ROA}_{\mathrm{i}, \mathrm{t}}+\beta_{2} \operatorname{ROS}_{\mathrm{i}, \mathrm{t}}+\beta_{3} \mathrm{CFO}_{\mathrm{i}, \mathrm{t}}+\beta_{7}$ Firm's Size $_{\mathrm{i}, \mathrm{t}}+\beta_{8} \mathrm{Lev}_{\mathrm{i}, \mathrm{t}}+\varepsilon_{\mathrm{i}, \mathrm{t}}$} \\
\hline Variable & $\begin{array}{l}\text { Unstandardized } \\
\text { Coefficient }(B)\end{array}$ & $\begin{array}{r}\text { Standardized } \\
\text { Coefficient (Beta) }\end{array}$ & (T) & Sig. \\
\hline Constant & 38743329 & & & \\
\hline $\mathrm{ROA}_{i, t}$ & -219666 & -.165 & -2.061 & $* .040$ \\
\hline $\operatorname{ROS}_{i, t}$ & 24803 & .072 & .953 & .341 \\
\hline $\mathrm{CFO}_{\mathrm{i}, \mathrm{t}}$ & 13381 & .005 & .069 & .945 \\
\hline Firm's Size ${ }_{i, t}$ & -5697402 & -.195 & -2.644 & $* .009$ \\
\hline Lev. i,t & 84475.678 & .089 & 1.334 & .184 \\
\hline $\mathrm{R}^{2}$ & \multicolumn{4}{|l|}{.089} \\
\hline Adj. $\mathrm{R}^{2}$ & \multicolumn{4}{|l|}{.069} \\
\hline $\mathrm{F}$ & \multicolumn{4}{|l|}{4.442} \\
\hline Sig. & \multicolumn{4}{|l|}{.001} \\
\hline
\end{tabular}

a. Predictors:(Constant)ROA ${ }_{i, t}, \mathrm{ROE}_{i, t}, \mathrm{CFO}_{\mathrm{i}, \mathrm{t}}$, Firm's Size $_{\mathrm{i}, \mathrm{t}}$ Lev. $_{\mathrm{i}}$,

b. Dependent variable: EM

c. $\quad *$ Significant at the level $\leq 5 \%$.

Information appears in table (4) demonstrates that a linear relationship between the traditional performance indicators and the phenomenon of earnings management, is existed. The computed f-value equals 4.442, with a computed coefficient of significance of zero. When the coefficient of significance is compared with the predetermined corresponding one, which equals 0.05 , it is apparent that computed one is lower than the predetermined. Therefore, and based on this result, the null hypothesis is rejected; while it's alternative one, is accepted. This result means that traditional performance indicators have an effect on the phenomenon of earnings management, and plays a role in interpreting the quality of these earnings. Therefore, the result indicates that there is an effect of at least one indicator of these indicators, and it contributes in interpreting the variance of the dependent variable. Results reveal that the coefficient of determination $\left(\mathrm{R}^{2}\right)$ equals 8.9 percent, where this refers that traditional performance indicators interpret 8.9 percent in the total variance in the phenomenon of earnings management. This is also considered as an indicator for the existence of a linear relationship between the traditional performance indicators and earnings management phenomenon. In addition, this means that other factors, the study did not take into consideration, are affecting the phenomenon of earnings management.

To determine which indicator has the most significant effect in interpreting the earnings management phenomenon, beta coefficient had been used. Table (4) shows that the indicator which has the most significant effect on earnings management is Firm's Size (FS), where beta coefficient equals -.195. Actually, firm's size is followed by ROA, where its beta coefficient 
equals -.165. In addition, results indicate that the coefficient of significance for these indicators is less than 0.05 , which means that each of these indicators has a significant effect on interpreting earnings management phenomenon.

It can be concluded that the variables of Firms' Sizes and ROA, are able to interpret the phenomenon of earnings management, and it is through the effect of these indicators on limiting the practices of earnings management, there is a probability that the managements of those firms exercise the phenomenon. Therefore, through the restriction of managements' interventions in measurement, the disclosed financial information reflects, in a better form, the events that occurred during the accounting period. Based on these findings, it is believed that the inverse relationship between each of ROA, and the firms' size with the practice of earnings management, which was expected to be positive. Attributed to the interested bodies by reliable and relevant accounting information, measurement, disclosure, and earnings management practices, a regular supervision on this phenomenon is recommended. In addition to the role of auditors are required to take several actions to reduce the practices of earnings management, whenever indicators for such practices appear. In addition, the rules of corporate governance can restrict the practices of earnings management phenomenon, when applied. No prior researches reached to this conclusion.

\section{Testing the Second Hypothesis}

The second hypothesis had developed to test the ability of modern performance indicators (market and economic) to interpret the phenomenon of Earnings Management that the listed manufacturing firms in ASE may exercise.

Ho2: Modern performance indicators including market and economic indicators are unable to interpret the phenomenon of earnings management that the manufacturing listed firms in Amman Stock Exchange may exercise. 
Table 5. The Model and Statistics of Modern Performance Indicators

\begin{tabular}{|l|c|c|c|c|}
\hline \multicolumn{5}{|l|}{} \\
\hline
\end{tabular}

a. Predictors:(Constant)ROA ${ }_{i, t}, R_{i, t}$, CFO $_{i, t}$, Firm's Size $_{i, t}$ Lev. i,

b.Dependent variable: $\mathrm{ME}$

c. * Significant at the level $\leq 5 \%$.

d. $\quad * *$ Significant at the level $\leq 10 \%$.

Information appears in table (5) demonstrate the existence of a significant linear relationship between the modern performance indicators (market and economic) and earnings management phenomena. The computed f-value equals 9.123, with a computed coefficient of significance of zero. When the coefficient of significance is compared with the predetermined corresponding one, which equals 0.05 , it is apparent that computed one is lower than the predetermined one. Therefore, and based on this result, the null hypothesis is rejected while, it's alternative one is accepted. This result means that modern performance indicators (market and economic) have an effect on the phenomenon of earnings management, and that these factors play a role in interpreting the phenomenon of earnings management. This means that there is an effect of at least one indicator among the modern performance indicators, and that contributes in interpreting the variance of the dependent variable. Results revealed that the coefficient of determination $\left(\mathrm{R}^{2}\right)$ equals 16.8 percent, where this refers that modern performance indicators interpret 16.8 percent in the variance of earnings management phenomenon. This is considered as indicator for the existence of linear relationship between the modern performance indicators and earnings management phenomenon.

To determine which modern performance indicator has the most significant effect on interpreting the phenomenon of earnings management, beta coefficient had been used. Table (5) shows that the indicator which has the most significant effect on earnings management where beta coefficient for this indicator equals -.322. Tobin's q comes next to EVA at beta 
coefficient of -0.151 . In addition, results indicate that the coefficient of significance for these indicators is less than 0.05 , which approves the significant effect of these indicators in interpreting the phenomenon of earnings management.

It can be concluded that EVA and Tobin's-q have ability to interpret phenomenon of earnings management, through restricting the practices of earnings management that firms' managements may exercise, and through the restricting these managements interventions in measurement, disclosure, and recognition of items appearing in the financial statements.

\section{Testing Branch Hypotheses}

Table (6) shows the results of testing the ability of each modern performance indicators in interpreting earnings management phenomena of the listed manufacturing firms in ASE.

Table 6. Results of Branch Hypotheses Testing

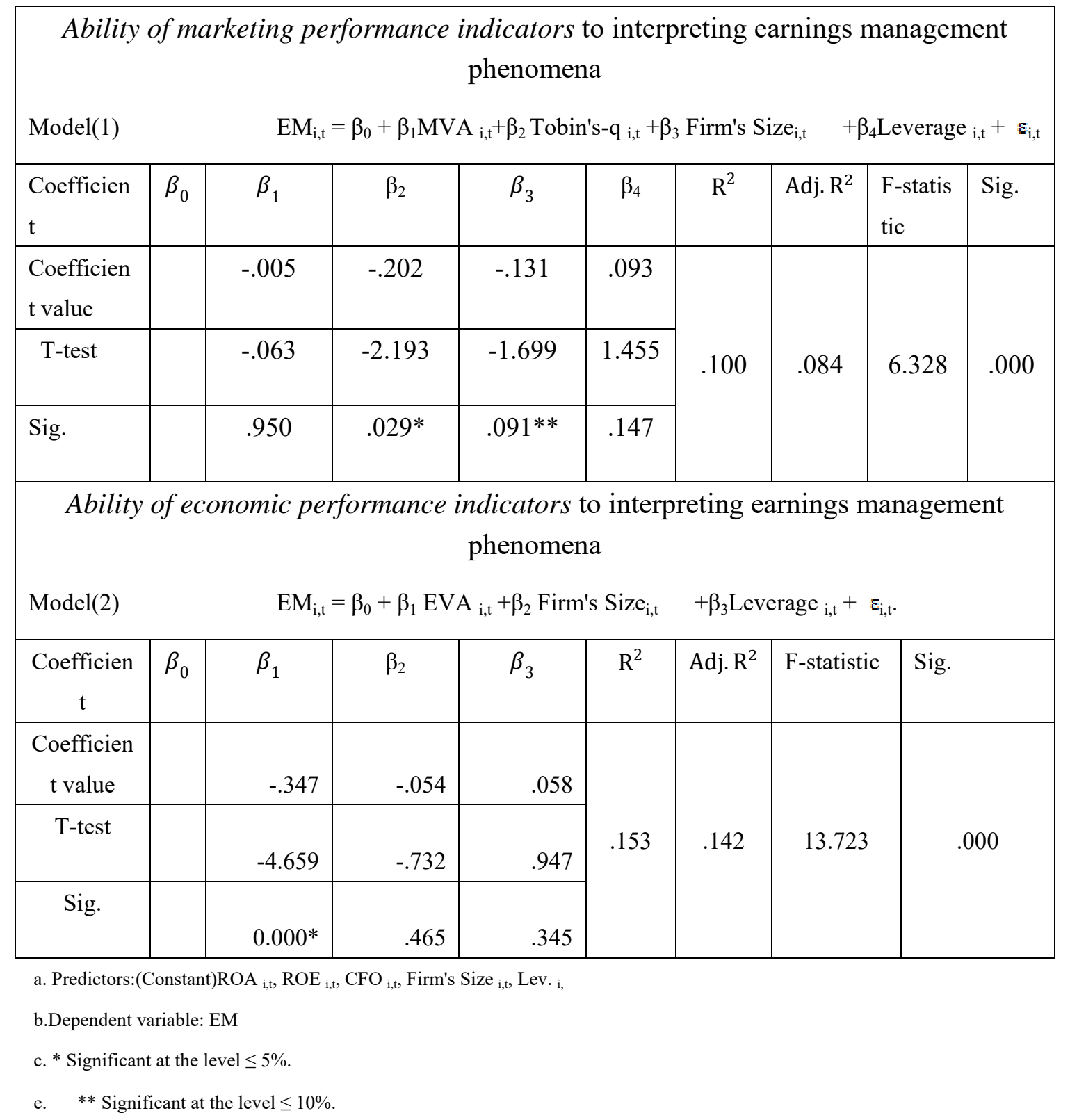


The first branching hypothesis text is again presented, in its null form, as follows:

Ho $_{21}$ : Indicators of market performance included the Added Market Value and the Firm's Opportunity of Growth (Tobin's-Q, are unable to interpret the phenomenon of earnings management that may be exercised by the listed manufacturing firms in Amman Stock Exchange.

The results of multiple linear regression method for Model (1) are shown in table (6). Based on information appears in the table, a linear relationship exists between the indicators of the market performance and the phenomenon of earnings management, since f value equals 6.328 , with zero coefficient of significance. Because the computed coefficient of significance is less than the predetermined one, which equals 0.05 , the null hypothesis is rejected, whereas the alternative one, which refers to the existence of an effect of audit office size on the quality of reported earnings, is accepted. The results also indicate that the value of the related coefficient of determination (adjusted $\mathrm{R}^{2}$ ) equals 10 percent, which means that 10 percent of the change in the earnings management can be attributed to the indicators of market performance. This is also can be considered as a good indicator for the existence of a linear relationship between market performance indicators and earnings management phenomenon. In addition, results demonstrate that the coefficient of the Tobin's-q is significant and negative and equals -0.202 . Moreover, the table shows that the computed $t$-value equals -2.193 , with a computed coefficient of significance of less than 0.05 .

The second branching hypothesis had developed to measure the ability economic performance indicators in interpreting earnings management phenomena that may be exercised by the listed manufacturing firms in ASE. The test of the second branching hypothesis is again presented, in its null form, as follows.

Ho22: Economic performance indicators represented by the Economic Value Added is unable to interpret the phenomenon of earnings management that may be exercised by the listed manufacturing firms in Amman Stock Exchange.

Information appears in table (6) shows the results of multiple linear regressions for model number (2), which shows the effect of economic performance indicators on interpreting the earnings management phenomena that the listed manufacturing firms in ASE may exercise. Results reveal the existence of a significant linear relationship between economic performance indicators and earnings management phenomenon, where f-value equals 13.723, with zero coefficient of significance. It is notable that the computed coefficient of significance, which equals zero, is less than the predetermined one, which equals 0.05 . The value of the computed coefficient of significance is of statistical significance. Because the computed level of significance is less than the corresponding predetermined one, the null hypothesis is rejected, while the alternative on is accepted. This means that the economic performance indicators contribute in interpreting the earnings management phenomena. The coefficient of determination (adjusted $\mathrm{R}^{2}$ ) equals 14.2 percent, which means that the economic performance indicators can interpret 14.2 percent of the change taking place in the phenomenon of earnings management. This is a good indicator for the existence of a linear relationship between economic performance indicators and the phenomenon of earnings 
management. In addition, results demonstrate that the coefficient of the EVA is significant and negative and equals -0.347 . Moreover, the table shows that the computed t-value equals -4.659 , with a computed coefficient of significance of less than 0.05 .

\section{Conclusions and Findings}

The main objective of the study is to investigate the Ability of Traditional and Modern Performance Indicators in interpreting the phenomenon of earnings management that the listed manufacturing firms in ASE may exercise. Based on the data analysis and hypotheses testing, the study finds that the listed manufacturing firms in ASE are still exercising the phenomenon of earnings management, but at a lower level based on the analysis of data. In other word, firm have enough or acceptable of earnings quality. In addition, the study shows that a linear regression relationship exists between the traditional and modern performance Indicators to interpret earnings management phenomena. The results indicate that there is a significant as well inverse relationship between (FS), (ROA) in one hand and earnings management phenomenon on the other hand, which approves that traditional performance indicators has a significant effect in interpreting earnings management phenomenon. The study also finds that Modern Performance Indicators have an ability to interpret earnings management phenomenon, where the results indicate that there is a significant, as well inverse relationship between (EVA), (Tobin's-q) and earnings management. The study concludes that (EVE) is an effective indicator in interpreting the earnings management phenomena that the listed manufacturing firms in ASE may exercise. However, the study does not demonstrate a significant relationship between CFO, Lev. ratio, ROS and MVA with earnings management phenomenon. In my opinion the indicators of value added, especially EVA, are now recognized as important tools of performance measurement, particularly in advanced economies by adopting it as a corporate strategy. Based on these results, the study provides many recommendations to the interested parties and the most important ones that companies should disclose the economic value added in the financial statements, to enable investors and related parties to know the amount of value-added that lead to increase the wealth of shareholders. Also these indicators can help managers to consider all costs of capital. In addition, these indicators can be used with other indicators such as (ROA, ROE,...) to evaluate firm's performance. The other recommendation in future research take another scale to measure earnings management, and set other variables as control variable such as company risk, corporate governance rule, and audit quality.

\section{References}

Al Dabbas, M. (2007). The Ability of Informational Content for the Economic and Accounting Measures on Assessing Firms Performance. Egyptian Journal for Commercial Studies, Commerce College, 31(1). Mansoura university.

Al Khalayleh, M. (2001). The Relationship Between a Number of Accounting Performance Indicators And Market Performance Indicators. Deirast Journal Administrative Sciences, Jordanian University, 28(21).

Al-Sartawi, A, Hamdan, A, Mushtaha, S., \& Abu Ijela, I. (2013). The Effect of Audit 
Committees on Earnings Management Empirical Study on Manufacturing listed Companies before the International Financial Crisis. An-Najah University Journal for Research Humanities, 27(4), 819-846.

Bagaeva, Alexandra. (2010). The Quality of Published Accounting Information in Russia, Faculty of Economics and Business Administration, of Accounting, University of Oulu Finland, 1-51.

Bellovary, J, L, Giacomino, D, L, \& Akers, M, D. (2005). Earnings Quality: It's Time to Measure and Report. The CPA Journal, 32-37.

Boardman, A. E., \& Vining, A. R. (1989). Ownership and Performance in Competitive Environment: A Comparison of the Performance of Private, Mixed, and State-Owned Enterprises. Journal of Law and Economics, 32(1), 1-33. http://dx.doi.org/10.1086/467167

Chan, K, Chan, L, Jegadeesh, N. \& Lakonishok J. (2006). Earnings Quality and Stock Returns, Journal of Business, 79(3), 1041-1082.

Dechow, P, M., \& Dichev, I, D. (2002). The Quality of Accruals and Earnings: The Role of Accrual Estimation Errors. The Accounting Review, 77, 35-59.

Dechow, P, M., Saloan, R, G., \& Sweeny, A, P. (1995). Detecting Earnings Management. The Accounting Review, 70, 193-225.

Farinha, J., \& Moreira, J, A. (2007). Dividends and Earnings Quality: The Missing Link? Working Paper University of Porto, 1-43.

Fisher, F.M., \& McGowan, J.J. (1983). On the Misuse of Accounting Rate of Returns to Infer Monopoly Profits. American Economic Review, 73(1), 65-86.

Ghosh, A., \& Moom, D. (2010). Corporate Debt Financings Earnings Quality, Journal of Business Finance \& Accounting, 37(5-6), 538-559. http://dx.doi.org/10.1111/j.1468-5957.2010.02194.x

Grant, J.L. ( 1996). Foundations of EVA for Investment Managers. The Journal of Portfolio Management, 23(1). http://dx.doi.org/10.3905/jpm.1996.409573

Gujarati, D. N. (2003). Essential of Econometrics. Fourth Edition, McGraw-Hill Irwin, United States.

Haddad, F., \& Haddad S. (2003). The Relationship between Stock Market Prices and Future Accounting Profits: An Empirical Study on Jordanian Public Shareholding Industrial Firms. Derasat Journal: Administrative Sciences, Jordanian University, 30(2).

Hamdan, A. (2012). Factors Influencing the Level of Earnings Quality: Evidence from the Jordanian Industrial Corporations. IUG Journal of Economics and Business, 20(1), 265-301.

Healy,P., \& Whalen,J. (1999).A Review of the Earning Management Literature and its Implications for Standard Setting. Accounting Horizons, December, 365-383. http://dx.doi.org/10.2139/ssrn.156445 
Irala, L. R. (2005). EVA: The Right Measure of Managerial Performance? Indian Journal of Accounting and Finance, 119(2), 1-10. http://ssrn.com/abstract=944420

Jones, Jennifer, J. (1991). Earnings Management During Import Relief Investigations. Journal of Accounting Research, 29(2), 193-228.

Lo, K. (2007). Earnings Management and Earnings Quality. Working Paper; Sauder School of Business; the University of British Columbia; Available on Line at: www.SSRN Electronic Library. http://dx.doi.org/10.1016/j.jacceco.2007.08.002

Mashayekhi, B., Talebi, A., \& Bahavarnia, V. (2007). Eva Versus Earnings: Evidence from Iran. International Journal of Accounting and Information Management, 18(1). http://dx.doi.org/10.1108/ijaim.2010.36618aad.006

Naimi, S. ( 2012). Forecasting the Performance and Profitability of Companies Using the Equation of Tobin'sq: An Empirical Study on a Sample of Listed on the Iraq Stock Exchange Companies. Accounting and Financial Studies Journal, 7((20).20-37.

Nakhaei, H, Abdul Hamid, N, Anuar, M., \&Hakimpoor, H. (2013). Evaluation of Company Performance with Accounting and Economic Criteria in Bursa Malaysi. Journal of Global Business and Economics, 6(1), 49-62.

Nassirzadeh. F. salehi, M., \& Alaei, S. (2012). A Study of the Factors Affecting Earnings Management: Iranian Overview. Science Series Data Report, 4(2), 22-27. http://dx.doi.org/10.5296/ijafr.v4i2.5674

O`Byrne, S. (1996). EVA and Market Value. Journal of Applied Corporate Finance, 9, 116-125.

Ongeri,B. O. (2014). Economic Value - Accounting Value Nexus: -The Effect of Accounting Measures on Economic Value Added Amongst the Kenyan Commercial Banks. Global Journal of Contemporary Research in Accounting, Auditing and Business Ethics, 1(3), 182-200.

Panahaian, H, \& Hosseini, M, M. (2013). The Effects of Performance Criteria Including Accounting, Market, and Economy on the Quality of Financial Reporting: A Case Study on Tehran Stock Exchange. Management Science Letters, pp 107-118. http://dx.doi.org/10.5267/j.msl.2012.11.009

Panigrahi,S.K., Zainuddin,Y., \& Azzan, A. (2014). Comparing Traditional and Economic Performance Measures for Creating Shareholders Value: a Perspective from Malaysia. International Journal of Academic in accounting, Finance and Management Sciences, 4(4), 280-289.

Peixoto,S. (2002). Ecoomic Value Added: Application to Portuguese Public Companies. Journal of Account Portuguese, 3, 25-40. http://dx.doi.org/10.2139/ssrn.302687

Radwan, A. J. (2011). Evaluating the Relationship between the Indicators of Economic and Accounting Performance and Stock Returns. Applied on Shareholding Listed Firms in 
Saudi Stock Exchange. The Scientific Journal of Commerce and Financing, Egypt, 2(1).

Richardson, S., Sloan, R., Soliman, M., \& Tuna, I. (2005). Accrual Reliability, Earnings Persistence and Stock Prices. Journal of Accounting and Economics, 39(3), 473-485. http://ssrn.com/abstract $=521062$

Schipper, K, \& Vincent, L. (2003). Earnings Quality. Accounting Horizons, 17, 97-110.

Sloan, R, G. (1996). Do Stock Prices Fully Reflect Information in Accruals and Cash Flows about Future Earnings? The Accounting Review, 71(3), 289-315. http://www.jstor.org/stable/248290

Stern, J., \& Stewart, B.G. (1995). The EVA Fianacial Management System. Journal Of Applied Corporate Financial, 33. http://dx.doi.org/10.1111/j.1745-6622.1995.tb00285.x

Teets, W, R. (2002). Quality of Earnings: An Introduction to the Issues in Accounting Education Special Issues. Issues in Accounting Education, 17(4), 355-360. http://dx.doi.org/10.2308/iace.2002.17.4.335 